\title{
Age Structure and Growth Characteristics of the Endemic Fish Oxynoemacheilus anatolicus (Nemacheilidae) in Düğer Creek, Mediterranean region of Turkey
}

\author{
Deniz İnnal ${ }^{1}($ )
}

Cite this article as: Innal, D. (2019). Age structure and growth characteristics of the endemic fish Oxynoemacheilus anatolicus (Nemacheilidae) in Düğer Creek, Mediterranean region of Turkey. Aquatic Sciences and Engineering, 34(3), 80-85.

ORCID IDs of the authors: D.i.: 0000-0002-1686-0959

'Burdur Mehmet Akif Ersoy University, Department of Biology, Burdur, Turkey

Submitted:

25.03.2019

Revision Requested

03.06.2019

Last Revision Received

12.06.2019

Accepted:

22.06.2019

Online published:

30.07.2019

Correspondence:

Deniz İnnal

E-mail:

innald@yahoo.com

(C) Copyright 2019 by Aquatic

Sciences and Engineering

Available online at

https://dergipark.org.tr/ase

\begin{abstract}
The present study reports the age and growth properties of Burdur Loach, Oxynoemacheilus anatolicus Erk'akan, Özeren \& Nalbant, 2008 caught from the Düger Spring Creek (Burdur-Turkey) and is currently listed as an endangered species. 100 specimens of $O$. anatolicus, which ranged in size between 2.5 and $8.6 \mathrm{~cm}$ in total length, 0.14 and $5.90 \mathrm{~g}$ in total weight, were collected during the study period. Of all the $O$. anatolicus examined, 5 were immature, 50 were female, and 45 were male. The overall sex ratio in the populations matches the expected value of 1:1 in a normal population. The otolith readings indicated the presence of five age classes (I-V). Length-weight relationships were fitted by the equation $W=0.0082 L^{3.0402}(p<0.05)$ for both sexes combined and this indicated that growth was positive allometric. The condition factor values were calculated and ranged from 0.64 to 1.19. The obtained data was compared with available results from close species. This study provided first baseline data related to length-weight relationship, age, sex ratio and condition factor for $O$. anatolicus - a species whose populations have been threatened due to various ecological changes in its habitats, leading to increased concern and the need for conservation.
\end{abstract}

Keywords: Freshwater, Endemic, Burdur Loach, Karstic spring

\section{INTRODUCTION}

Anatolia is characterized by high levels of biodiversity and a high density of endemic species, Its geological history has played a key role in the diversification of freshwater fish species (Demirsoy, 2002; Kuru, Yerli, Mangıt, Ünlü, \& Alp, 2014; Çiçek, Sungur Birecikligil, \& Fricke, 2015; Çiçek, Fricke, Sungur, \& Eagderi, 2018). The loach genus Oxynoemacheilus has undergone major diversification in Anatolia, where more than 30 species have been reported (Froese and Pauly, 2019).

Members of the genus Oxynoemacheilus, commonly known as stone loaches, are small fish living in the fresh waters of Asia and its islands,
Europe, and northeast Africa. They inhabit a variety of water bodies ranging from mountain streams to salty rivers in dry lowlands (Jouladeh-Roudbar, Eagderi, \& Hosseinpour, 2016). Most of them are very rare and have a limited distribution area. Despite the high diversity and endemism of Oxynoemacheilus genus in Turkey, knowledge about its biology and population dynamics are still limited. Most of the available studies have focused mainly on lengthweight relationships (Gaygusuz et al., 2012; Erk'akan, Innal, \& Özdemir, 2013, 2014; Innal, Özdemir, \& Dogangil, 2015; Birecikligil, Çiçek, Öztürk, Seçer, \& Celepoğlu, 2016; Özcan \& Altun, 2016; Yazıcıoğlu \& Yazıcı, 2016). 
The Burdur Endorheic Basin has a great diversity of natural ecosystems including wetlands, warm and hot springs, and saline and freshwater lakes. Because of the introduction of alien or translocated fish species and building of dams for agricultural purposes, many endemic fishes have become rare and endangered here (Küçük, Gülle, Innal, \& Güçlü, 2016; personal observation, Deniz Innal). The Burdur Endorheic basin provides an essential spawning and rearing habitat for many loach species, including the Burdur loach (Küçük et al., 2016). Burdur loach has been reported at input locations in Karamanlı Dam Lake (Erk'akan, Özeren, \& Nalbant, 2008), Başpınar Creek (Küçük et al., 2016), Düger Spring (Freyhof, Erk'akan, Özeren \& Perdices, 2011; Innal et al., 2017) and Pınarbaşı Creek (Innal \& Giannetto, 2017).

While the subject's populations have been threatened due to various ecological changes in its habitats, leading to increased concern and the need for conservation, there is not sufficient information available about its biological features. This study provided first baseline data related to length-weight relationship, age, sex ratio and condition factor for $O$. anatolicus.

\section{MATERIALS AND METHODS}

The study was carried out in Düger Creek between March 2014 and December 2014 (6 sampling events). Düger Creek is a small, karst system in the southwest of Turkey, situated in the Düger Vil-

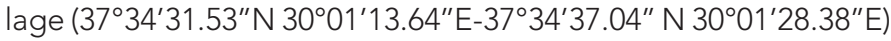
close to the city of Burdur (Burdur Endorheic Basin). Water quality parameters were measured at the surface at the start of each field trip. Temperature $\left({ }^{\circ} \mathrm{C}\right)$, salinity, $\mathrm{pH}$ and dissolved oxygen (mg/l) concentration were measured using a YSI water meter (Professional Plus). A total of 100 O. anatolicus speciemens were collected using electroshock equipment.

After being caught, the fish samples were transported to the laboratory where their size (total length; $\mathrm{cm}$, referred to as $\mathrm{L}$ in the text and weight; $g$, referred to as $W$ in the text) were measured and weighed to the nearest $1.0 \mathrm{~mm}$ and $0.01 \mathrm{~g}$, respectively. The otoliths of individuals were used for age determination (The roman numerals indicate a subjective classification of ages). Length-weight relationships were estimated for the total sample and separated by sex, according to the equations suggested by Ricker (1975), $W=a L^{b}$. Where $W=$ mass in grams; $L=$ total length in centimeters. $a=$ constant; $b=$ constant described as isometric or allometric growth type. The value of Condition factor, $\mathrm{K}$ was calculated following Froese (2006), $K=100 * W / L^{3}$. The slopes of length-weight regressions were compared to 3 using Student's t-test to ascertain if the species grew isometrically. Size-frequency distributions between sexes were conducted using the t-test and Kolmogorov-Smirnov two-sample test. A Chi-square test was used to identify the sex-ratio divergence from the expected value of 1:1 (male:female).

\section{RESULTS AND DISCUSSION}

Düger Creek is a natural karst spring system leading to Lake Burdur. The bottom is generally muddy or made up of small gravel. A range of water quality parameters of Düger Creek were measured (Figure 1)

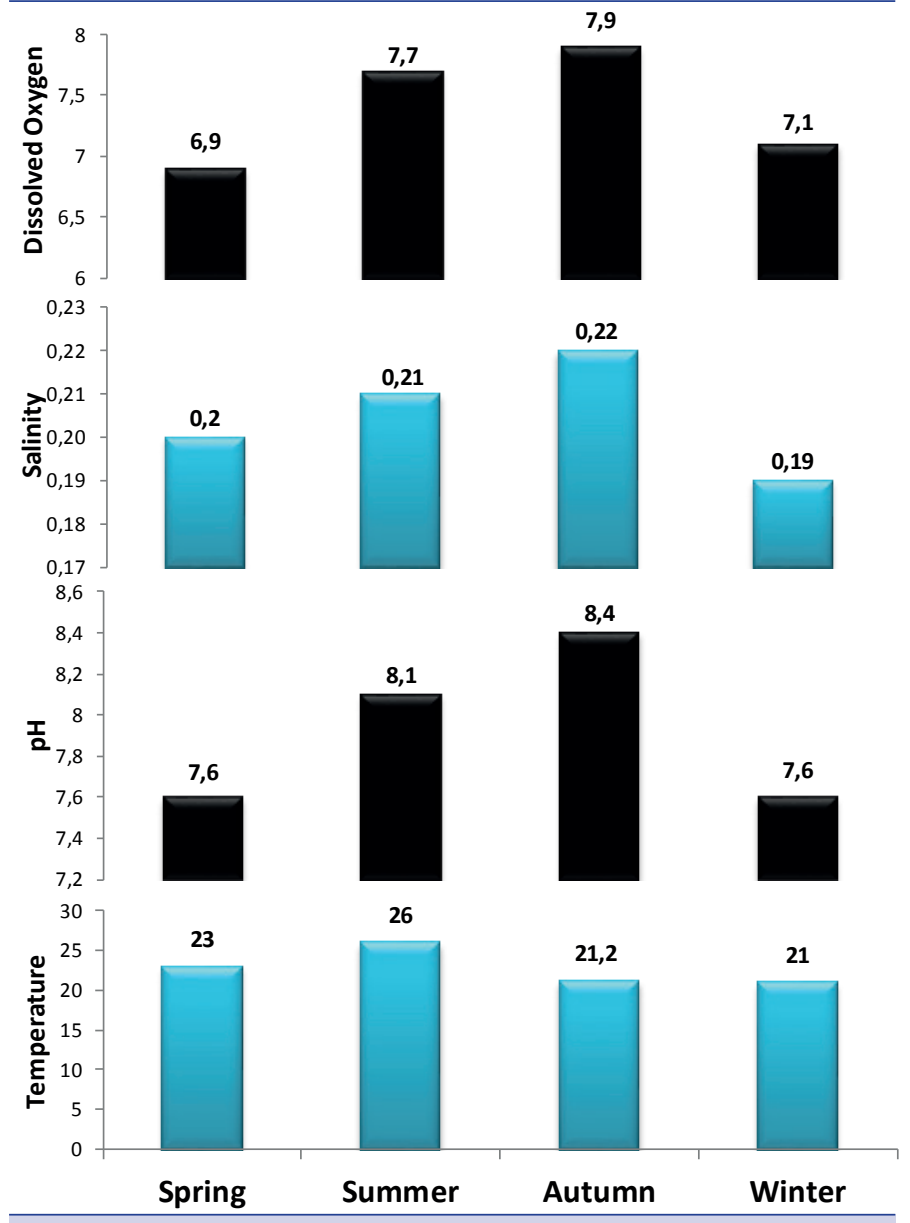

Figure 1. Water quality parameters of Düger Creek.

O. anatolicus was observed in slow-flowing waters where the vegetation zone was dense. Pseudophoxinus burduricus, Gambusia holbrooki, Oxynoemacheilus theophilii and Oxynoemacheilus anatolicus were reported from Düger Spring (Innal et al., 2015; Innal et al., 2017). Within the sample area, bottom salinity ranged from 0.19-0.22 ppt, surface temperature ranged from $21^{\circ} \mathrm{C}-26^{\circ} \mathrm{C}, \mathrm{pH}$ ranged from $7.6-8.4$ and dissolved oxygen (mg/L) ranged from 6.9-7.9. This species is well adapted to the warm-water spring zone of Düger Creek.

Although a high species diversity of Genus Oxynoemacheilus exists in Turkey, little is known about their life history. The ecology of $O$. anatolicus has been reported in aquatic systems in terms of systematics (Erk'akan et al., 2008), distribution (Freyhof et al., 2011; Küçük et al., 2016; Innal \& Giannetto, 2017) and parasites (Innal et al., 2017). This work, however, is the first study on age and growth for Burdur Loach in Turkey, so no comparison is possible with other studies of this species.

The sex and age compositions of $O$. anatolicus are shown in Table 1.

The 100 individuals of 0 . anatolicus used for the age determination consisted of 45 (45\%) males, 50 females (50\%) and 5 (5\%) juveniles. The female-male ratio for all fish combined was 1.11:1 
Table 1. The sex and age compositions of $O$. anatolicus

\begin{tabular}{lcccccccc}
\hline \multirow{2}{*}{ Age } & \multicolumn{2}{c}{ Juvenile } & \multicolumn{2}{c}{ Female } & \multicolumn{2}{c}{ Male } & \multicolumn{2}{c}{ Total } \\
\cline { 2 - 9 } & $\mathbf{N}$ & $\%$ & $\mathbf{N}$ & $\%$ & $\mathbf{N}$ & $\%$ & $\mathbf{N}$ & $\%$ \\
\hline I & 5 & 5 & 2 & 2 & 3 & 3 & 10 & 10 \\
II & & 21 & 21 & 29 & 29 & 50 & 50 \\
III & & 11 & 11 & 7 & 7 & 18 & 18 \\
IV & & 15 & 15 & 4 & 4 & 19 & 19 \\
V & & & 1 & 1 & 2 & 2 & 3 & 3 \\
Total & & 5 & 50 & 50 & 45 & 45 & 100 & 100
\end{tabular}

Table 2. Length frequency distribution of $O$. anatolicus

\begin{tabular}{|c|c|c|c|c|c|c|}
\hline \multirow{2}{*}{ Length intervals $(\mathrm{cm})$} & \multicolumn{5}{|c|}{ Age groups (in years) } & \multirow{2}{*}{ Total } \\
\hline & I & II & III & IV & v & \\
\hline $2-2.9$ & 3 & & & & & 3 \\
\hline 3-3.9 & 7 & 13 & & & & 20 \\
\hline $4-4.9$ & & 20 & & & & 20 \\
\hline $5-5.9$ & & 17 & 6 & & & 23 \\
\hline $6-6.9$ & & & 12 & 3 & & 15 \\
\hline 7-7.9 & & & & 16 & & 16 \\
\hline $8-8.9$ & & & & & 3 & 3 \\
\hline Total & 10 & 50 & 18 & 19 & 3 & 100 \\
\hline Range TL & $2.50-3.40$ & $3.20-5.60$ & $5.20-6.80$ & $6.20-7.90$ & $8.40-8.60$ & $2.5-8.6$ \\
\hline Mean TL $\pm S D$ & $2.98 \pm 0.25$ & $4.49 \pm 0.64$ & $6.01 \pm 0.48$ & $7.24 \pm 0.48$ & $8.47 \pm 0.12$ & $5.26 \pm 1.55$ \\
\hline Range W & $0.14-0.31$ & $0.29-1.53$ & $1.07-3.11$ & $2.02-5.31$ & $5.45-5.90$ & $0.14-5.90$ \\
\hline Mean $\mathrm{W} \pm \mathrm{SD}$ & $0.23 \pm 0.06$ & $0.86 \pm 0.37$ & $1.94 \pm 0.55$ & $3.36 \pm 0.81$ & $5.65 \pm 0.23$ & $1.61 \pm 1.40$ \\
\hline
\end{tabular}

Table 3. Estimated length weight parameters of Oxynoemacheilus species

\begin{tabular}{|c|c|c|c|c|c|c|c|c|}
\hline Species & Locality & b & a & $r^{2}$ & $\begin{array}{l}\text { TL(Min- } \\
\text { Max) }\end{array}$ & $\begin{array}{l}\text { W(Min- } \\
\text { Max) }\end{array}$ & $\mathbf{N}$ & Reference \\
\hline O. mesudae & Küfe Creek & 2.628 & 0.0161 & 0.95 & $6.6-8.9$ & $2.2-5.2$ & 14 & Erk'akan et al., 2014 \\
\hline O. evreni & Çayır Creek & 2.788 & 0.0128 & 0.92 & $5.4-9.4$ & $1.4-6.7$ & 27 & Erk'akan et al., 2014 \\
\hline O. theophilii & Bozçay Creek & 2.898 & 0.01 & 0.94 & $3.1-5.6$ & $0.25-1.18$ & 10 & Innal et al., 2015 \\
\hline O. samanticus & Karaboğaz Creek & 2.919 & 0.00851 & 0.92 & $4.5-8.6$ & $0.6-4.3$ & 40 & Erk'akan et al., 2014 \\
\hline O. angorae & Kılıçözü Stream & 2.929 & 0.0098 & 0.96 & $3.5-9.8$ & $0.38-6.58$ & 103 & Yazıcıoğlu \& Yazıcı, 2016 \\
\hline O. theophilii & Dalaman Stream & 2.989 & 0.011 & 0.93 & 6.4-7.9 & $2.51-4.88$ & 10 & Innal et al., 2015 \\
\hline O. anatolicus & Düger Creek & 3.04 & 0.0082 & 0.98 & $2.5-8.6$ & $0.14-5.90$ & 100 & PRESENT STUDY \\
\hline O. theophilii & Cüneyt Creek & 3.07 & 0.007 & 0.96 & 6.6-10.5 & 2.3-11 & 17 & Innal et al., 2015 \\
\hline O. angorae & Kızılırmak River Basin & 3.102 & 0.008 & 0.94 & $2.8-8.6$ & $0.22-6.18$ & 127 & Birecikligil et al., 2016 \\
\hline O. theophilii & Düger Spring & 3.188 & 0.007 & 0.94 & $3.9-5.8$ & $0.56-2.09$ & 13 & Innal et al., 2015 \\
\hline O. eregliensis & Melendiz Creek & 3.196 & 0.005 & 0.98 & $1.65-10.3$ & $0.1-7.3$ & 76 & Erk'akan et al., 2013 \\
\hline O. angorae & Sögütözü Beynam & 3.228 & 0.00622 & 0.99 & $4.4-8.3$ & $0.8-6.6$ & 24 & Erk'akan et al., 2014 \\
\hline O. angorae & Balıklı Stream & 3.237 & 0.006 & 0.88 & $4.7-7.3$ & $0.86-3.56$ & 30 & Gaygusuz et al., 2012 \\
\hline O. simavicus & Karaçaltı Creek & 3.261 & 0.0044 & 0.95 & 4.6-7.1 & $0.6-2.5$ & 17 & Erk'akan et al., 2014 \\
\hline O. theophilii & Yiğitler Creek & 3.293 & 0.004 & 0.98 & $5.5-8.9$ & $1.1-5.4$ & 9 & Innal et al., 2015 \\
\hline O. hamwii & Gölbaşı Lake & 3.52 & 0.0021 & 0.96 & $5.0-8.8$ & $0.6-3.65$ & 28 & Özcan and Altun, 2016 \\
\hline
\end{tabular}


and Chi square test analysis conducted on sex ratio showed that the difference was not statistically significant $(P>0.05)$. The ages of the captured specimens ranged from I to $V$ years and the second group was dominant in the population, followed by age IV (19\%), III (18\%), I (10\%), and V (3\%) age groups.

Females were caught in higher numbers in this study. A higher proportion of females has also been reported for other members of the Nemacheliidae family, for species such as 1.0/0.63 (f/m) for O. angorae in Kılıçözü Stream (Yazıcıoğlu \& Yazıcı, 2016). 1/0.81 $(\mathrm{f} / \mathrm{m})$ for $O$. tigris from Murat River (Koyun, Ulupınar, Mart, \& Tepe, 2016).

Length frequency distribution of $\mathrm{O}$. anatolicus is given in Table 2

The specimens of 0 . anatolicus ranged from 2.5 to $8.6 \mathrm{~cm}$ in total length and from 0.14 to $5.9 \mathrm{~g}$ in total weight. Total length ranged from 3.1 to $8.4 \mathrm{~cm}$ in males, from 3.1 to $8.6 \mathrm{~cm}$ in females and from 2.5 to $3 \mathrm{~cm}$ in juveniles. Weight ranged from 0.208 to $5.9 \mathrm{~g}$ in males, from 0.203 to $5.6 \mathrm{~g}$ in females and from 0.14 to $0.285 \mathrm{~g}$ in juveniles. The mean total length and weight of females were higher than males. No significant difference was observed in mean length and weight between sexes $(P>0.05)$.

The total length of $O$. anatolicus ranged from 2.5 to $8.6 \mathrm{~cm}$, which fits well within the known values (Table 3 ) while the minimum length observed in this study was close to the value reported for Oxynoemacheilus angorae from the Kızılırmak River Basin (Birekcikliğil et al., 2016). The maximum length was closer to known reported values for some species; Oxynoemacheilus angorae from the Kızılırmak River Basin (Birekcikliğil et al., 2016) and Sögütözü Beynam (Erk'akan et al., 2014), for Oxynoemacheilus hamwii from Gölbaşı Lake (Özcan \& Altun, 2016), for Oxynoemacheilus mesudae from Küfe Creek (Erk'akan et al., 2014), for Oxynoemacheilus samanticus from Karaboğaz Creek (Erk'akan et al., 2014), for Oxynoemacheilus theophilii from Yiğitler Creek (Innal et al., 2015). In population structure, female individuals of $O$. anatolicus showed wider length range, mean length and weight than males.

Length and weight frequency distributions and length-weight relationships $\mathrm{W}=\mathrm{aTL} \mathrm{L}^{\mathrm{b}}$ (in $\mathrm{g}$ and $\mathrm{cm}$ ) for $\mathrm{O}$. anatolicus from Düger Creek are given in Figure 2.

Among all the individuals, dominancy was in the total length range of $3-6 \mathrm{~cm}$ and dominancy was in the weight range of 0.14 $2 \mathrm{~g}$ (Figure 2). The length frequency distributions of males and females were not significantly different. Length-weight relationships was calculated using the data of $100 \mathrm{O}$. anatolicus specimens. This was found to be $W=0.0082 L^{3.0402}\left(R^{2}=0.98\right)(p<0.05$; $95 \% \mathrm{Cl}$ of b: 3.022-3.054) for all individuals. The calculated value of (b) exponent for female, male and combined sexes was 3.0286 $(p<0.05), 3.0498(p<0.05)$ and $3.0402(p<0.05)$, respectively. These values indicate that the fish had positive allometric growth. " $b$ " values of $O$. anatolicus were not significantly different between the sexes. The regression models in the study showed no differences in terms of growth patterns between males and females of 0 . anatolicus. The $r$ value of 0.98 indicates a high correlation degree of length and weight.
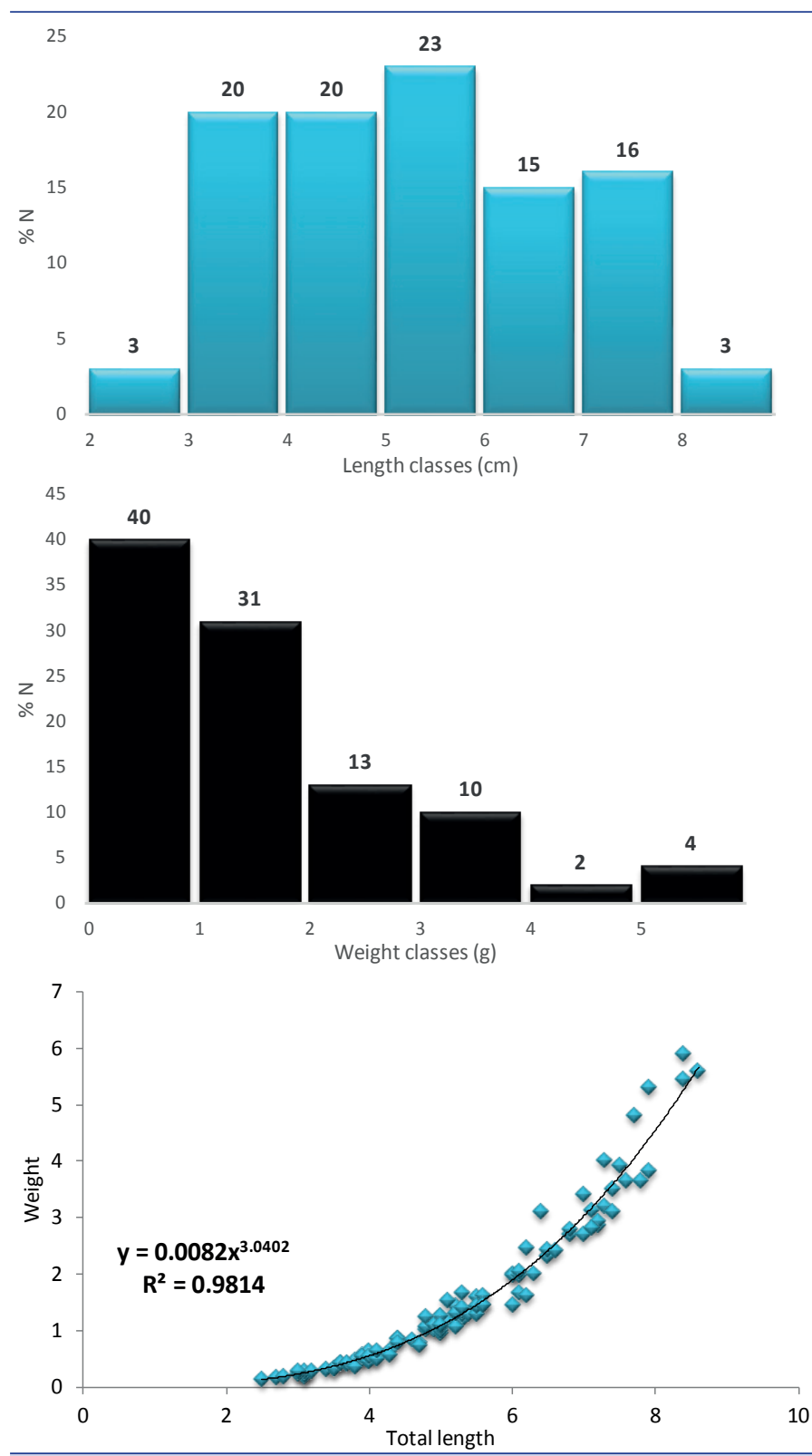

Figure 2. Length and weight frequency distributions and length-weight relationships for $O$. anatolicus from Düger Creek.

Length-weight relationship (LWR) parameters have basic uses in fish stock assessment and fisheries management (Froese, 2006). This paper provides the first published reference of the lengthweight for $O$. anatolicus. Relationships between length and weight for species of Oxynoemacheilus genus have been described by several authors, and both isometric and allometric growth from various water bodies have been reported for species of Oxynoemacheilus genus (Table 3). The b value of Oxynoemacheilus species in Turkey has been shown to range from 2.63 to 3.52 (Table 3).

Allometric growth of Oxynoemacheilus genus determined in this study was in accordance with results reported in earlier studies 


\section{1,40}

\section{1,20

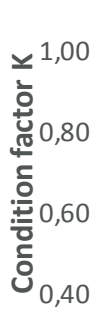

0,20

0,00

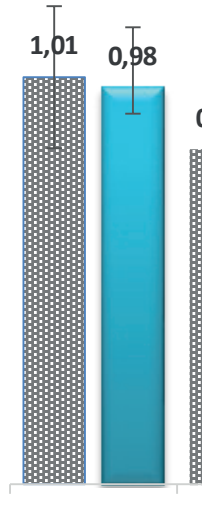

16.03.2014

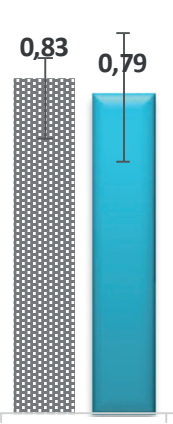

3.05.2014

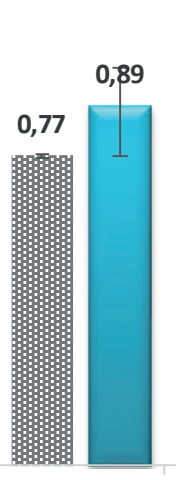

6.07.2014
期 Female $\square$ Male

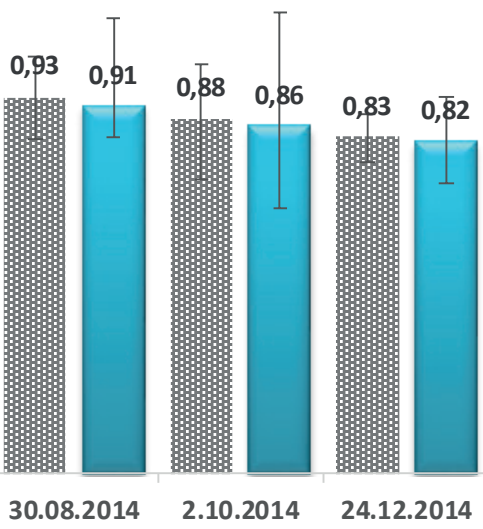

Dates

Figure 3. Seasonally condition factor of $O$. anatolicus.

(Gaygusuz et al., 2012; Erk'akan et al., 2013; Erk'akan et al., 2014; Innal et al., 2015; Birekcikligil et al., 2016; Özcan \& Altun, 2016). The factors affecting the $b$ value have been reported by various authors (Tesch, 1971; Moutopoulos \& Stergiou, 2002; Froese, 2006). Variations in growth type and $b$ values from different areas may be attributed to one or more factors, including different physico-chemical parameters of systems, flora and fauna compositions of systems. sampling designs, sampling properties and characters of species (sex, length range, diet, parasites).

Graphical presentations of the seasonal condition factor for $O$. anatolicus studied are shown in Figure 3.

Condition factor $(K)$ values for female samples were generally higher than those of the males. The mean $\mathrm{K}$ values for female, male and combined sexes were $0.90,0.86$ and 0.88 respectively (Fig. 3). The results showed that there were no variations in condition factors between sexes of the $O$. anatolicus collected from Düger Creek. The condition factor of $O$. anatolicus showed seasonal variation - it was noticed that $\mathrm{K}$ was higher when fish entered into the maturation phase during the month of March, while for rest of the seasons $\mathrm{K}$ showed lower values.

The mean condition factor which is a measure of the suitability of the environmental factor for growth of the species obtained for this study was 0.88 and ranged from 0.64 to 1.19. Mean condition factor value was close to the value (0.86) documented by Yazıcıoğlu \& Yazıcı, (2016) for Oxynoemacheilus angorae from the Kılıçözü Stream and also relatively lower than the value (0.94) reported by Birecikligil et al. (2016) for Oxynoemacheilus angorae from the Kızılırmak River Basin (Birekcikliğil et al., 2016). Differences in mean condition factors of males and females in this study were not statistically significant.

The Burdur Loach was listed as endangered as a result of dam construction and pollution (Freyhof, 2014). The species is sympatric with 3 native species; Pseudophoxinus burduricus, Cobitis battalgili, $O$. theophili, of which the first two are endemic to Ana- tolia. During the study period in Düger Creek, one alien species, Gambusia holbrooki was caught. An increasing population of $G$. holbrooki may threaten the population of $O$. anatolicus.

Anthropogenic water pollution is another important disturbance factor. The anthropogenic water pollution sources include human waste, ruminant animal farming and chicken egg industry discharges. Chemical pesticides, often used in agriculture, may constitute a high risk to $O$. anatolicus. In addition, the construction of roads for Marble Mining affects the habitat quality of Düger Creek. A minor threat is excessive water abstraction that alters the normal creek flow and may restrict the movement of the fish along the creek channel.

\section{CONCLUSIONS}

This study highlights that growth characteristics for Burdur Loach are not much different from species in the same genus (Table 3). Length-weight relationship exhibited positive allometric growth patterns in the $O$. anatolicus collected from Düger Creek. The overall sex ratio in the populations matched the expected value of $1: 1$ in a normal population. Condition factor values of $O$. anatolicus in Düger Creek were close to the reported values for other species of the same genus. The best conditions for the fish were recorded during the month of March.

Because of the threat to $O$. anatolicus populations by loss of suitable habitats, conservation efforts are required. Data on lengthweight relationship, age, sex ratio and condition factor for Burdur Loach inhabiting Düger Creek have been presented in this paper for the first time.

It could be concluded that the findings of this study will contribute to the knowledge of bioecology of $O$. anatolicus. Further studies on the reproductive biology and conservation practices are urgently required for this endangered species.

Acknowledgements: The author would like to thank Buğrahan Doğangil from the Faculty of Science and Arts at Burdur Mehmet 
Akif University for his contribution to the study, which consisted of data collection during the fieldwork and otolith studies.

Ethics Committee Approval: This study was carried out in accordance with animal welfare and trial ethics. All procedures were performed in accordance with the Law on Veterinary and Medical Activities and National Animal Welfare Act.

Conflict of Interest: Author has no conflict of interest to report.

\section{REFERENCES}

Birecikligil, S.S., Çiçek, E., Öztürk, S., Seçer, B. \& Celepoğlu, Y. (2016). Length-length, length-weight relationship and condition factor of fishes in Nevşehir Province, Kızılırmak River Basin (Turkey). Acta Biologica Turcica, 29(3), 72-77.

Çiçek, E., Sungur Birecikligil, S. \& Fricke, R. (2015). Freshwater fishes of Turkey: a revised and updated annotated checklist. Biharean Biologist, 9(2), 141-157.

Çiçek, E., Fricke, R., Sungur, S. \& Eagderi, S. (2018). Endemic freshwater fishes of Turkey. FishTaxa, 3(4), 1-39.

Demirsoy, A. (2002). Genel Zoocoğrafya ve Türkiye Zoocoğrafyası: Hayvan Coğrafyası, Meteksan, Ankara, 1007 sayfa.

Erk'akan, F., Özeren, S.C. \& Nalbant, T.T. (2008). Two new species of Stone Loaches from Turkey (Teleostei: Nemacheilidae). Journal of Fisheries International, 3(4), 115-119.

Erk'akan, F., Innal, D. \& Özdemir, F. (2013). Length-weight relationships for ten endemic fish species of Anatolia. Journal of Applied Ichthyology, 29, 683-684. [CrossRef]

Erk'akan, F., Innal, D. \& Özdemir, F. (2014). Length-weight relationships for some endemic stone and spine loach species in Anatolia. Journal of Applied Ichthyology, 30(1), 244-245. [CrossRef]

Freyhof, J., Erk'akan, F., Özeren, C. \& Perdices A. (2011). An overview of the western Palaearctic loach genus Oxynoemacheilus (Teleostei: Nemacheilidae), Ichthyological Exploration of Freshwaters, 22(4), 301-312.

Freyhof, J. (2014). Oxynoemacheilus anatolicus. The IUCN Red List of Threatened Species 2014:e.T19384476A19848952. http://dx.doi. org/10.2305/IUCN.UK.20141.RLTS.T19384476A19848952. en. Downloaded on 10 April 2018

Froese, R. (2006). Cube law, condition factor and weightlength relationships: history, meta-analysis and recommendations. Journal of Applied Ichthyology, 22, 241-253. [CrossRef]

Froese, R. \& Pauly. D. (2019). FishBase. World Wide Web electronic publication. www.fishbase.org, version (02/2019).

Gaygusuz, Ö., Aydın, H., Emiroğlu, Ö., Top, N., Dorak, Z., Gürsoy Gaygusuz, Ç., Başkurt, S. \& Tarkan, A.S. (2012). Length-weight relationships of freshwater fishes from the western part of Anatolia, Turkey. Journal of Applied Ichthyology, 29, 285-287. [CrossRef]
Innal, D., Avenant-Oldewage, A., Dogangil, B., Stavrescu-Bedivan, M. M., Ozmen, O. \& Mavruk, S. (2017). Susceptibility of endemic and nonindigenous fish to Lernaea cyprinacea (Copepoda: Lernaeidae): a case study from Düger Spring Creek (Burdur-Turkey). BulletinEuropean Association of Fish Pathologists, 37(3), 100-109.

Innal, D. \& Giannetto, D. (2017). Age Structure and Length-Weight Relationship of Non-native Redbelly Tilapia Coptodon zillii (Gervais, 1848) (Cichlidae) in the Pınarbaşı Spring Creek (Burdur, Turkey). Acta Zoologica Bulgarica, Suppl. 9, 111-116.

Innal, D., Özdemir, F. \& Dogangil, B. (2015). Length-Weight relationships of Oxynoemacheilus theophilii (Teleostei: Nemacheilidae) from Turkey. International Journal of Fisheries and Aquatic Studies, 2(4), 249-250.

Jouladeh-Roudbar, A., Eagderi, S. \& Hosseinpour, T. (2016). Oxynoemacheilus freyhofi, a new nemacheilid species (Teleostei, Nemacheilidae) from the Tigris basin, Iran. FishTaxa, 1(2), 94-107.

Koyun, M., Ulupınar, M., Mart, A. \& Tepe, Y. (2016). Seasonal prevalence of Allocreadium isoporum (Loos, 1894) (Digenea: Allecreadiidae) in Oxynoemacheilus tigris (Osteichthyes: Balitoridae) (Steindachner, 1897) from Murat River, Eastern Anatolia, Turkey. Biharean Biologist, 10(1), 1-3.

Kuru, M., Yerli, S., Mangıt, F., Ünlü E. \& Alp A (2014). Fish biodiversity in inland waters of Turkey. Journal of Academic Documents for Fisheries and Aquaculture, 1(3), 93-120.

Küçük, F., Gülle, I., Innal, D. \& Güçlü, S.S. (2016). Burdur ili Balıkları: Biyoçeşitlilik Envanteri, Popülasyon ve Habitat Durumları, Mehmet Akıf Ersoy Üniversitesi Fen Bilimleri Enstitüsü Dergisi, 7(Ek Sayı 1), 232-239.

Moutopoulos, D.K. \& Stergiou, K.I. (2002). Length-weight and lengthlength relationships of fish species from the Aegean Sea (Greece). Journal of Applied Ichthyology, 18, 200-203. [CrossRef]

Özcan, G. \& Altun, A. (2016). Length-weight and length-length relationships for four freshwater fish species from Gölbaşı Lake (Hatay), Turkey. Journal of Applied Ichthyology, 32(6), 1350-1352. [CrossRef]

Ricker, W. E. (1975). Computation and interpretation of biological statistics of fish populations. Bulletin of the Fisheries Research Board of Canada, 191, 382 p.

Tesch, F.W. (1971). Age and growth. In: W.E. Ricker (Ed.). Methods for assessment of fish production in fresh waters. Blackwell Scientific Publications, Oxford. pp: 98-130.

Yazıcıoğlu, O. \& Yazıcı, R. (2016). The Length-Weight, Length-Length Relationship and Condition Factor of Angora Loach, Oxynoemacheilus angorae (Steindachner, 1897) Inhabiting Kılıçözü Stream in Kızılırmak River Basin (Central Anatolia, Turkey). Turkish Journal of Agriculture Food Science and Technology, 4(12), 1165-1168. [CrossRef] 